\title{
Автоматичний режим ендовенозного електрозварювання в лікуванні варикозної хвороби нижніх кінцівок
}

\author{
В. С. Горбовець ${ }^{1}$ С. І. Саволюк ${ }^{1}$, О. О. Дядик ${ }^{1}$ М. М. Гвоздяк ${ }^{1}$ А. А. Балабай ${ }^{2}$ \\ 'Національна медична академія післядипломної освіти імені П. Л. Шупика, м.Київ, \\ ${ }^{2}$ Національний медичний університет імені О. О. Богомольця, м. Київ
}

\section{Automatic regime of endovenous electric welding in treatment of varicose disease of the lower extremities}

\author{
V. S. Horbovets ${ }^{1}$, S. I. Savoluk ${ }^{1}$, O. O. Dyadyk ${ }^{1}$, M. M. Gvozdiak ${ }^{1}$, A. A. Balabai ${ }^{2}$ \\ ${ }^{1}$ Shupyk National medical Academy of Postgraduate Education, Kyiv, \\ ${ }^{2}$ Bogomolets National Medical University, Kyiv
}

\section{Реферат}

Мета. Вивчити ефективність застосування автоматичного режиму ендовенозного електрозварювання (EBE3) в лікуванні варикозної хвороби нижніх кінцівок (ВХНК).

Матеріали і методи. Автоматичний режим ЕВЕЗ досліджували на видалених сегментах великої підшкірної вени (ВПВ), визначаючи температуру, опір та морфологічні зміни. Проаналізовані результати застосування методу у 56 пацієнтів 3 ВХНК С2 - С5 класів (за класифікацією СЕАР - clinic, etiolody, anatomy, pathogenesis): 21 чоловіка та 35 жінок у віці 18 63 років. Критерії оцінки: післяопераційний біль (ПБ), анатомічний результат, ускладнення. Втручання виконували під інфільтраційною анестезією 0,125\% розчином бупівакаїну. Результати визначали під час ультразвукового ангіосканування через 14 діб, 3 і 6 міс.

Результати. Протягом автоматичного циклу EBE3 (5 - 12 с) відбувалася оклюзія ВПВ при температурі 55 - $75^{\circ} \mathrm{C}$. Визначена альтерація вени на глибину ендотеліального та субендотеліального шарів без пошкодження паравазальної клітковини. ПБ був помірний. Фіброзну трансформацію (ФТ) ВПВ через 6 міс встановили у 55 (98,2\%) пацієнтів. Екхімози та парестезію спостерігали у 4 (7,1\%) та 2 (3,6\%) пацієнтів.

Висновки. Автоматичний режим ЕВЕ3, який грунтується на взаємозв'язку електричних параметрів зварювання та опору тканин, забезпечує оклюзію ВПВ з подальшою ФТ, супроводжується низьким нагрівом вени та виключає вплив суб'єктивних факторів на результати операції.

Ключові слова: варикозна хвороба нижніх кінцівок; ендовенозне електрозварювання; автоматичне електрозварювання живих тканин.

\section{Abstract}

Objective. To study up the application efficacy of automatic regime in endovenous electric welding (EVEW) in treatment of varicose disease of the lower extremities (VDLE).

Materials and methods. Automatic regime of EVEW was investigated on excised segments of big subcutaneous vein (BSV), registering the temperature, resistance and morphological changes. The results of the method application in 56 patients, suffering VDLE Classes C2 - C5 (in accordance to the CEAP classification were analyzed - clinic, etiology, anatomy, pathogenesis): in 21 men and 35 women ageing $18-63$ yrs old. Postoperative pain, anatomic result and complications have served as a criteria for the outcome estimation. The intervention was performed under infiltrative anesthesia using $0.125 \%$ solution of bupivacaine. The results were determined using ultrasound angioscanning in 14 days, 3 and 6 mo.

Results. During automatic cycle of EVEW $(5-12 \mathrm{sec})$ the BSV occlusion in $55-75^{\circ} \mathrm{C}$ temperature have occurred. The vein alteration on the depth of endothelial and subendothelial layers without damage of endothelial layer and paravasal cellular tissue was determined. Postoperative pain was moderate. Fibrous transformation (FT) of BSV in 6 mo was determined in 55 (98.2\%) patients. Ecchimosis and paresthesia were observed in 4 (7.1\%) and $2(3.6 \%)$ patients.

Conclusion. Automatic regime of EVEW, which is based on interrelationship of electric parameters of welding and resistance of tissues, providing the BSV occlusion with further FT, is accompanied by low heat of vein and excludes the impact of subjective factors on results of the operation.

Keywords: varicose disease of the lower extremities; endovenous electric welding; automatic electric welding of living tissues.

Застосування ендовенозної лазерної коагуляції (ЕВЛК) та радіочастотної абляції (РЧА) в лікуванні варикозної хвороби нижніх кінцівок (ВХНК) пов'язане з вибором оптимальних параметрів енерговпливу, ризиком виникнення опікових, тромботичних і неврологічних ускладнень та використанням високовартісного устаткування, що обумовлює актуальність пошуку нового методу термічної облітерації [1 - 4].
Ми запропонували метод ендовенозного електрозварювання (EBE3), розроблений та впроваджений у клінічну практику протягом 2015 - 2016 рр. [5, 6].

Удосконалення методу та зварювальних інструментів (3I) уможливило застосування EBE3 в автоматичному режимі [7].

Мета дослідження: вивчити ефективність ЕВЕ3 в автоматичному режимі в лікуванні ВХНК. 


\section{Матеріали і методи дослідження}

Вплив ЕВЕЗ в умовах біоімітаційної моделі досліджували на видалених сегментах великої підшкірної вени (ВПВ) довжиною 10 см та діаметром від 4,5 до 22 мм. Протягом автоматичного робочого циклу реєстрували динаміку температури венозної стінки та електричних параметрів зварювання. Результати визначали за візуальними та морфологічними змінами вен та паравазальної жирової клітковини.

Вивчені результати клінічного застосування EBE3 в автоматичному режимі в лікуванні 56 пацієнтів з ВХНК С2 - С5 клінічних класів (за класифікацією СЕАР): 21 (37,5\%) чоловіка та 35 (62,5\%) жінок у віці від 31 до 65 років. Оперативні втручання виконували під інфільтраційною анестезією (IA) 0,125\% розчином бупівакаїну в обсязі до 5 мл на 1 см вени. В післяопераційному періоді призначали ненаркотичні аналгетики протягом однієї доби та препарати мікронізованої очищеної фракції флавоноїдів протягом 2 міс. Цілодобову та щоденну еластичну компресію кінцівки застосовували протягом 3 діб та 1 міс відповідно.

Результати визначали під час операції та на 2, 7-му та 14-ту добу за даними ультразвукового ангіосканування (УЗАС). Поточні анатомічні результати визначали через 1 та 3 міс, кінцеві - через 6 міс. У післяопераційному періоді застосовували суб'єктивну оцінку інтенсивності післяопераційного болю (ПБ) за 10-бальною цифровою рейтинговою шкалою (ЦРШ) та визначали наявність ускладнень - опіку, тромбофлебіту, парестезії та екхімозів площею більше $20 \mathrm{~cm}^{2}$.

Для морфологічного аналізу препарати вен забарвлювали гематоксиліном та еозином, пікрофуксином за ван Гізоном. Для оцінки змін колагену застосовували забарвлення для виявлення еластичних волокон (Elastic Stain Kit). Дослідження проводили за допомогою світлооптичного мікроскопа «ZEISS» (Німеччина) з системою обробки даних «Axio Imager. A2».

Характеристика обладнання. Пристрій для ЕВЕЗ складається з генератора струму - апарата для електрозварювання живих тканин ЕК 300М («Свармед», Україна) та 3I оригінальної конструкції [7]. Генератор забезпечує 4 режими роботи: автоматичне та ручне зварювання, коагуляція та різання. Робоча частина 3І складається 3 двох різнополярних електродів, які мають форму еліпсоїду для введення через розріз або циліндричну форму - для пункційного введення 3 калібрами 4 та 2 мм, довжиною 5 та 1,5 см відповідно.

Схема роботи автолатичного режиму ЕВЕЗ. У генераторі формується високочастотна напруга, різниця потенціалів прикладається до електродів робочої частини 3I. Струм, що проходить крізь провідне середовище, обумовлює його нагрівання протягом робочого циклу, що супроводжується оклюзією шляхом денатурації та дегідратації білків крові та венозної стінки. Параметри робочого циклу: напруга від 10 до 100 В, частота змінного струму 50 - 500 кГц з модуляцією від 0,1 до 250 кГц, опір тканини від 0,1 до 1000 Ом, температура $50-75^{\circ} \mathrm{C}$, глибина поширення нагріву 1,5 - 2 мм. Тривалість робочого циклу визначається за коефіцієнтом відносного опору:

$$
\mathrm{k}=\mathrm{R}_{\mathrm{i}}\left(\mathrm{t}_{\mathrm{i}}\right) / \mathrm{R}_{0}\left(\mathrm{t}_{0}\right),
$$

де $\mathrm{R}_{\mathrm{i}}\left(\mathrm{t}_{\mathrm{i}}\right)$ - поточний опір біологічної тканини,

$\mathrm{R}_{0}\left(\mathrm{t}_{0}\right)$ - початковий опір.

Якщо досягнено певне значення k, яке фіксує блок обробки інформації, пристрій припиняє подачу напруги для запобігання надлишкового нагріву вени.

Техніка клінічного застосування автоматичного режиму ЕВE3. ЗІ у ВПВ вводять із пункційних доступів або iз пахового доступу. Після ультразвукової (УЗ) локації робочої частини 3І в заданій ділянці ВПВ виконують ІА по ходу ВПВ. Хірург активує пристрій, що супроводжується звуковим сигналом, який триває до закінчення робочого циклу та протягом якого відбувається електротермічна оклюзія ділянки вени на довжину, рівну довжині робочої частини 3І. Процес оклюзії контролюють за допомогою УЗ датчика, який розташовують над ділянкою зварювання. По закінченні робочого циклу ЗІ та УЗ датчик переміщують в наступну ділянку вени з повторенням процесу по всій довжині цільового сегмента ВПВ.

\section{Результати}

У всіх епізодах стендових досліджень вплив ЕВЕ3 приводив до структурних змін вен, які супроводжувалися відповідною динамікою температури, сили струму та опору тканин. На початку робочого циклу відбувався різкий спазм вени, який поширювався на 0,5 - 1 см від полюсів робочої частини 3І, та стрімко зростала сила струму. В подальшому спостерігали потовщення венозної стінки та явища дегідратації з виділенням пари. В цей момент зафіксовані максимальна сила струму і мінімальний опір тканин. Закінчення робочого циклу збігалося з моментом розвитку денатурації венозної стінки та супроводжувалося зниженням сили струму та зростанням опору до максимального значення.

Робочий цикл у різних ділянках ВПВ, незалежно від діаметра, тривав від 5 до 12 с. За даними контактної термометрії венозна стінка в ділянці зварювання нагрівалась до 55 $75^{\circ} \mathrm{C}$. Візуальних та морфологічних ознак ураження паравазальної жирової клітковини не спостерігали, в тому числі у разі повторення робочих циклів в одній ділянці вени.

У препаратах вен, забарвлених гематоксиліном та еозином, визначено звуження та зірчастий вигляд просвіту, утворення оптично порожніх, місцями зливних бульозних структур та часткове розшарування стінки вени і відокремлення адвентиції за рахунок спазму. Спостерігали фрагментацію та деструкцію еластичних волокон у внутрішньому та середньому шарах.

Під час клінічного застосування методу робочий цикл у різних ділянках ВПВ також тривав від 5 до 12 с, впродовж яких спостерігали розвиток УЗ ознак оклюзії ділянок ВПВ - спазм судини, потовщення іiі стінок та перекриття просвіту гіперехогенними масами.

Після оперативних втручань порушень загального стану та функції активної ходи у пацієнтів не спостерігали. На ПБ не скаржились 18 (32,1\%) пацієнтів. Інтенсивність ПБ у решти 38 (67,8\%) пацієнтів не перевищувала 3 балів за ЦРШ (біль помірний), а його тривалість не перевищувала 24 год.

На 2, 7-му та 14-ту добу у всіх пацієнтів встановлена оклюзія цільових сегментів ВПВ. На 30-ту добу у 17 
(30,4\%) пацієнтів виявлені ділянки ВПВ з ознаками ФТ. Кінцевий анатомічний результат у вигляді ФТ встановлено у 55 (98,2\%) пацієнтів, причому у 38 (67,9\%) пацієнтів розвиток ФТ визначено через 3 міс після операції. Реканалізацію з відновленням рефлюксу спостерігали у 1 (1,8\%) пацієнта.

Опіки, тромбофлебіт та запальні інфільтрати в ділянках застосування ЕВЕ3 не виникали. Екхімози площею понад

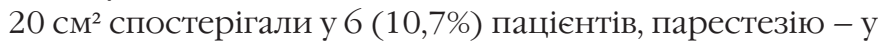
4 (7,1\%). Регрес екхімозів відбувався протягом 7 - 14 діб, парестезія зберігалася до 2 міс.

\section{Обговорення}

За результатами стендових досліджень встановили ефективний та дозований вплив автоматичного режиму EBE3, параметри якого генеруються відповідно до поточного опору в кожній конкретній ділянці вени. Електротермічна дегідратація супроводжується зростанням опору з припиненням робочого циклу в момент денатурації венозної стінки, що запобігає надлишковому нагріву та коагуляції. Це явище в умовах екстравазальної компресії спостерігається незалежно від діаметра вен, калібру та довжини робочої частини 3I.

За даними термометрії та морфологічних досліджень встановили, що автоматичний режим EBE3 у порівнянні з ЕВЛК і РЧА супроводжується значно меншими нагрівом та глибиною альтерації венозної стінки. Зокрема, у разі застосування ЕВЛК температура на поверхні вени може перевищувати $150{ }^{\circ} \mathrm{C}[1,2]$, внаслідок чого коагуляція охоплює всі шари венозної стінки та поширюється на паравазальні тканини [4]. В той же час після EBE3 спостерігали морфологічні зміни, подібні до змін, описаних при РЧА: ураження ендотеліального та середнього шарів, деструкція колагенових волокон та відшарування адвентиції через спазм судини $[8,9]$.

Інтенсивність і тривалість ПБ, частота розвитку ФТ та ускладнень після застосування автоматичного режиму ЕВЕЗ суттєво не відрізняються від відповідних даних, наведених у наукових джерелах стосовно ЕВЛК і РЧА $[1,4$, $8-10]$.

\section{Висновки}

Автоматичний режим ЕВE3, який грунтується на взаємозв'язку електричних параметрів зварювання та опору тканин, забезпечує оклюзію ВПВ з подальшим розвитком ФТ, супроводжується низьким нагрівом вени та виключає вплив суб'єктивних факторів на результати операції.

\section{References}

1. Hudz IM. Dyskusiyni pytannya endovenoznoyi lazernoyi ablyatsiyi pry likuvanni khvorykh na varykoznu khvorobu. Klinichna flebologiya. 2015;8(1):17-8. [In Ukrainian].

2. Shahid KR, Dellon AL, Amrami KK, Spinner RJ. Sciatic and peroneal nerve injuries after endovascular ablation of lower extremity varicosities: case reports and review of the literature. Ann Plast Surg. 2015 Jan;74(1):64-8. doi: 10.1097/SAP.0000000000000193.

3. Kelleher D, Lane TRA, Franklin IJ, Davies AH. Socio-economic impact of endovenous thermal ablation techniques. Lasers Med Sci. 2014 Mar;29(2):493-9. doi 10.1007/s10103-013-1453-8.

4. Jacquet R. Treatment of lower limb varicose veins in 2015: The present and the future. Ann Dermatol Venereol. 2015 Aug-Sep;142(8-9):48392. doi: 10.1308/003588408X318228.

5. Palamarchuk VI, Horbovets VS, Khodos VA, Balatskiy RO, Bondarenko YuI. vynakhidnyky; Shupyk National Medical Academy of Postgraduate Education,

patentovlasnyk. Sposib obliteratsiyi velykoyi pidshkirnoyi veny. Patent Ukrainy No 113093. 2016 Grud 12. [In Ukrainian].

6. Savoluk SI, Horbovets VS, Gvozdiak MM, Kunkin DD, Krestianov MYU, Gerashchenko RA. Teoretychni experimentalni ta klinichni aspecty zastosuvanniyia endovenoznogo electrozvaruvaniya u likuvanni varycoznoi khvorobu nuzjnikh kintsivok. Endovascularna neirorentgenokhirurgia. 2017;(1):49-65. [In Ukrainian].

7. Horbovets VS, Kunkin DD, Kosakovsky AL, Makarov AV, Lubchenko AS, vynakhidnyky; Shupyk National Medical Academy of Postgraduate Education,

patentovlasnyk. Prystriy dlia endovenoznoyi obliteratsyi. Patent Ukrainy No 120462. 2017 List 10. [In Ukrainian].

8. Usenko OYu, Petrushenko VV, Tatarin AE. Vplyv radiochastotnoyi abliatsiyi ta endovenoznoyi lasernoyi koagulatsiyi na sudynnu stinku varykozno zmineniykh ven nyzjnih kintsivok. Visnyk morfologiyi. 2015;(2):5058. [In Ukrainian].

9. Proebstle TM, Alm BJ, Göckeritz O, Wenzel C, Noppeney T, Lebard C, et al. Five-year results from the prospective European multicentre cohort study on radiofrequency segmental thermal ablation for incompetent great saphenous veins. Br J Surg. 2015;102(3):212-8. doi:10.1002\%2Fbjs. 9679 .

10. Rasmussen L, Lawaetz M, Serup J, Bjoern L, Vennits B, Blemings A, Eklof B. Randomized clinical trial comparing endovenous laser ablation, radiofrequency ablation, foam sclerotherapy, and surgical stripping for great saphenous varicose veins with 3-year follow-up. J Vasc Surg Venous Lymphat Disord. 2013;1(4):349-56. doi:10.1016/j. jvsv.2013.04.008. 